\title{
A Testopia during COVID-19: Qualitative Study about Higher Education Institutions Examination (HEIE)
}

\section{COVID-19 Sırasında Bir Testopya: Yükseköğretim Kurumları Sınavı (YKS) Hakkında Nitel Araştırma}

Aylin SALTÜRK*

\author{
Ömay ÇOKLUK-BÖKEOĞLU**
}

Received: 08 April 2021

Research Article

Accepted: 28 July 2021

\begin{abstract}
Central exams are in the heart of Turkish education system since they are used for student selection and placement in transition to higher levels of education. The preparation process for central placement exams, which was already challenging for students and parents, may have become even more exhausting due to the changing educational paradigms during the COVID-19 pandemic. In this context, using the phenomenological model, this study aims to determine the student and parent views regarding the preparation for the Higher Education Institutions Examination (HEIE) during COVID-19 pandemic period. Semi-structured interviews were conducted with 20 high school seniors in an Anatolian High School in Afyonkarahisar Province during the 2020-2021 academic year, selected with the purposive sampling method, and of their parents, and the obtained data were analysed through content analysis method. Although stress is an ordinary part of the preparation period, new stress sources have formed during the pandemic, according to the findings obtained from this study. It has been seen that both the students and the parents have discussed higher visibility of socio-economic inequalities, limited student life experience, impacts of social isolation due to the implemented health and safety policies as the cons, and the opportunities to study harder and more autonomously as the pros. Parents have also evaluated children's being under their supervision during this period as one of the pros.
\end{abstract}

Keywords: Higher Education Institutions Examination, COVID-19 pandemic, admission exams.

ÖZ: Merkezi sınavlar seviyeler arası geçişte öğrenci seçme ve yerleştirme için kullanıldığından dolayı Türk eğitim sisteminin temelinde yer almaktadır. Doğası gereği öğrenci ve ebeveyn için zorlayıcı bir deneyim olan merkezi yerleştirme sınavlarına hazırlık süreci, COVID-19 hastalığı neticesinde değişen eğitim paradigmaları ve hastalığın bir pandemiye dönüşmüş olmasının getirdiği sorunlar nedeniyle daha da yıpratıcı bir hale gelmiş olabilir. Bu bağlamda fenomenolojik desenin kullanıldığı bu araştırmada COVID-19 pandemisi sürecinde merkezi yerleştirme sınavlarından biri olan Yükseköğretim Kurumları Sınavı'na (YKS) hazırlanmaya ilişkin öğrenci ve ebeveyn görüşlerinin belirlenmesi amaçlanmıştır. Amaçlı örnekleme yöntemiyle seçilen, 2020-2021 eğitim öğretim yılında Afyonkarahisar'da bir Anadolu lisesinde 12. sınıfa devam eden 20 lise öğrencisi ve onların ebeveynlerinden oluşan çalışma grubuyla yarı yapılandırılmış görüşmeler gerçekleştirilmiş ve elde edilen veriler içerik analiziyle çözümlenmiş̧ir. Stres, birçok ögrenci ve ailesi için sınava hazırlık sürecinin normal bir parçası olsa da araştırmadan elde edilen bulgular COVID-19 pandemisiyle birlikte yeni stres faktörlerinin devreye girdiğini göstermiştir. Hem öğrencilerin hem ebeveynlerin olumsuzluklar olarak sosyo-ekonomik eşitsizliklerin daha görünür hale gelmesini, sınırlı öğrencilik deneyiminin, uygulanan sağlık ve güvenlik politikaları nedeniyle sosyal izolasyonun etkilerini; olumlu unsurlar olarak daha fazla ve özerk çalışma imkânı olmasını ele aldıkları görülmüştür. Ebeveynler aynı zamanda bu süreçte çocuklarının kontrolleri altında olmasını da olumlu bir sonuç olarak değerlendirmiştir.

Anahtar kelimeler: Yükseköğretim Kurumları Sınavı, COVID-19 pandemisi, giriş sınavları.

\footnotetext{
* Res. Asst., Afyon Kocatepe University, Afyonkarahisar, Turkey, asalturk@ aku.edu.tr, https://orcid.org/0000-00034143-8917

** Prof. Dr., Ankara University, Ankara, Turkey, cokluk@education.ankara.edu.tr, https://orcid.org/0000-0002-38799204
}

\section{Citation Information}

Saltürk, A., \& Çokluk-Bökeoğlu, Ö. (2021). A Testopia during COVID-19: Qualitative study about Higher Education Institutions Examination (HEIE). Kuramsal Eğitimbilim Dergisi [Journal of Theoretical Educational Science], 14(4), 498-523. 
According to the data of Turkish Statistical Institute (TurkStat), young population (aged between 15-24) constitutes $15.6 \%$ of the total population in Turkey (TurkStat, 2019). While this situation may be an advantage for a developing country, it also brings along some problems regarding the education of the population in question (Baştürk, 2011). Looking through a historical point of view, there are a number of chronic problems associated with education in Turkey, just like in every other developing country. Most of these problems are related to frequent changes in the education system (Temli-Durmuş \& Kasa, 2015) and unequal opportunities in education (Günbayı et al., 2015; Kumandaş \& Kutlu, 2014). In this regard, among the factors feeding unequal opportunities, schools showing significant differences from each other in terms of equipment and physical conditions (Çıng1 et al., 2009), teacher qualifications and inadequate employment in schools (Ayvacı et al., 2014), sociocultural factors such as the environment (Coşkun, 2019) can be indicated. It is possible to see the reflections of unequal opportunities in the statistical data provided by Turkish Ministry of National Education (MoNE, 2020b), where schooling rate remains far below what it should be, and dramatic discrepancies exist in the success of the students in the exams for transition to higher levels. Within this context, education-related problems become the problem of not only the students but also their parents, namely, the whole society.

The fact that transition to higher education is based on examination (Y1lmaz \& Altınkurt, 2011) is one of the major problems, also defined as "the festering sore" (Arslan, 2004, p. 37), of Turkish Education System. An education system based on the central placement exam puts parents in trouble as well as students (Köse, 1999), and young people in this system get caught up in test booklets before they can experience their developmental period (Rutz \& Balkan, 2015). Additionally, this exam is far from providing feedback on the education (MoNE, 2010, as cited in Büyüköztürk, 2016, p. 349). Since these exams have grown into almost a 'struggle for existence' for both students and parents, students are raised as individuals deprived of skills to facilitate their lives and to be test-oriented only (Büyüköztürk, 2016). In this process, parents also try to get their children to receive academic support by sending them to extracurricular institutions to the extent possible (Gür et al., 2013; Tansel \& Bircan, 2005).

The problems of exams (Çelik, 2015; ÖSYM, 2017), employed for placement in higher education institutions and whose applications, scope and name have changed frequently from 1974 to the present (Gür \& Çelik, 2009) have remained the same. Considering students' struggles to move to the next level of education and overcome unequal opportunities and negative effects resulting from such struggles on them (Büyüköztürk, 2016; Cüceloğlu, 2013; Karslı \& Üstüner, 2001; Kutsal \& Bilge, 2012), it would not be wrong to state that these exams go beyond their purpose and that the primary purpose of education determined in the Basic Law of National Education (1973), has deviated from the goal of 'ensuring a healthy and productive adaptation of the young population to the society'.

Evaluating on a global scale, the education systems of different countries indeed have their own strengths and weaknesses. In parallel with the development level of the countries, it is seen that success in education has also increased. Technological developments have been integrated into education at full speed. At the same time, COVID-19 pandemic emerging in 2019 caused a global crisis due to rapid morbidity and mortality statistics (Tabish, 2020), with health and education being the leading 
sectors affected. Efforts to contain the epidemic and flatten the pandemic curve have brought along decisions to turn educational institutions into a (semi or full) state of closure. This undoubtedly has led to the serious disruption of the education sector, especially in certain countries (Malee-Bassett \& Arnhold, 2020).

With the announcement of the first COVID-19 case in Turkey on March 11, 2020 , the need for a two-week break to education arose. It was decided to continue remote education at all levels through online systems throughout the Spring semester (MoNE, 2020a; YÖK, 2020). Although plans for implementing hybrid education (blended learning) model were made for the fall semester of the 2020-2021 academic year, the plans were revised to continue online education with the primary and secondary education institutions due to the increase of the cases once again (MoNE, 2020a). Additionally, a similar proposal was made to higher education institutions within the framework of health and safety policies. As a result, the situation, beginning as a health crisis, soon affected the functioning of all systems in the society, leaving no option but to quickly move to distance education, irrespective of suitable infrastructure in education. At the beginning of the process, distance education was stated not being as efficient as face-to-face education; however, some of these views evolved with the arrangements made in time and some empirical research findings have been revealed about the positive results of distance education (Hodges et al., 2020).

Educational activities implemented remotely and online since almost the first day of the first COVID-19 case came up to date have reemphasized unequal opportunities and revealed unjust conditions of the students lacking necessary technical infrastructure to access the educational platforms (Saltürk \& Güngör, 2020). The inequalities in question were not limited to the access to courses. They stood as problems in terms of assessment and evaluation activities conducted for other purposes. In other words, distance education has inevitably become part of the new education paradigm while efforts have been made to ensure rapid integration of technology to implement assessment and evaluation processes (OECD, 2020). However, it is known that even the use of state-of-the-art infrastructures cannot prevent some technical problems that may occur during e-tests or several factors that may pose a threat to the validity and reliability of the tests (Chirumamilla et al., 2020; Hillier et al., 2020). Therefore, many educational institutions have tried to create equal environments and conditions by applying face-to-face exams (Dermo, 2009; OECD, 2020). It can also be considered that this situation arises as a necessity to secure equal opportunities in countries like Turkey, where inter-school differences are greater because it is impossible even to think of the participation of some students, who cannot join courses due to lack of technical means, in tests synchronically implemented. These tests should not only be considered limited to the exams for evaluating course success within the scope of formal education, but also central and large-scale exams that are the subject of this study should be considered. Given high participation rates in these exams and the repercussions of socio-economic inequalities, it is clear that implementing central placement examinations, being an important determinant of educational life, in an online environment is impossible. Indeed, central examinations planned to be implemented in 2020, for these reasons, were conducted as traditional paper and pencil tests, though belatedly, during the period when the pandemic was relatively taken under control within the framework of health policies (MoNE, 2020a; ÖSYM, 2020a). 
It is seen that Higher Education Institutions Examination (HEIE), which has significant impacts on such stakeholders as students, teachers and parents even under normal conditions in Turkey, being a "Country of Tests" (Baş \& Kıvilcım, 2019, p. 642), is likely to be more problematic due to the changing conditions with the pandemic. Thus, it was considered that analyzing the impacts of the exam in question in line with the views of the students and parents was of importance and to that end, answers to the following questions were sought:

1. How do students and parents evaluate the impact of pandemic on students during the preparation period for HEIE?

2. As for the concerns of both students and parents,

a. What are their concerns related to HEIE?

b. Have they changed during COVID-19 pandemic?

3. What do students and parents say about the advantages and disadvantages of the preparation period for HEIE during COVID-19 pandemic?

\section{Method}

\section{Ethical Procedures}

Before the research, the authorization of Committee of Scientific Research and Publication Ethics for Social Sciences and Humanities in Afyon Kocatepe University was sought and granted (decision no 2020/216 dated 20/11/2020). Participants were explained the purpose of the research as well as being provided with such information and assurance as the fact that the participation was voluntary, that their rights to withdraw from the research at any stage resided, that privacy of the identity information and anonymity would be protected, and that the information provided would only be used within the scope of a scientific research study. After such information, the consent of the participants was obtained, and interviews were conducted.

\section{Research Model}

This research study used a qualitative research model (Merriam, 2009), which deals with how people make sense of their experiences. The analysis of preparation period for central placement examination during COVID-19 pandemic based on the experiences of the students and parents complies with the phenomenological model. The findings obtained through phenomenological model, which allows in-depth evaluation of individuals' perceptions and views (Büyüköztürk et al., 2018), are based on subjective experiences of participants (Denzin \& Lincoln, 1998). This model, where the results are provided in a descriptive narrative method with direct speech reporting, allows for understanding participants based on their 'own expressions' (Patton, 1980, p. 22). The information obtained from the data is interpreted within the framework of themes and codes (Yıldırım \& Şimşek, 2011).

\section{Study Group}

This study aimed at interviewing people who would provide rich data in terms of preparation for HEIE during COVID-19 pandemic. To that end, the purposive sampling method (Patton, 2002) was used to determine the study group, where people to contribute more for this study were included. As was also stated by Patton (2002), the 
purposive sampling method is used in cases when there are limited sources in relation to a phenomenon subject to research. This method is eligible for determination and selection of cases enriched with the information required for the research. Thus, this method was used in this research study as a data collection method. At the first stage, being a student preparing for the exam and being a parent of these students were accepted as the preconditions of participation in this research. In addition, some characteristics such as strong self-expression skill, being accessible and volunteering were also considered. However, as it was further evaluated that students who were preparing for the exam to re-take it in the status of graduate could have different experience than those in the senior years of their high school education, the former were not included in the research. Data collection continued until the collected data was deemed sufficient in terms of quantity and diversity of the information it included in terms of the gender and success status of the students who continued their education in the 12th grade of high school and prepared for HEIE during the pandemic process as well as socio-economic level, gender, age of their parents.

The research data was collected following the decision dated November 23, 2020, taken for the second time on the implementation of distance education (MoNE, 2020a) due to the increase in COVID-19 cases. Within this context, it was decided to include in the study group the 12th-year students during the 2020-21 academic year, continuing their education remotely because of COVID-19 pandemic and preparing for HEIE, along with their parents. Data was collected from a total of 40 participants, including 20 students studying in an Anatolian High School in Afyonkarahisar Province and their parents through interviews. To ensure anonymity, each student (such as S1, S2, S3) and parent (such as P1, P2, P3) were given codes.

13 out of 20 students in the study group are female while 7 are male and their ages are between 17 and 18. The study group members' grade point averages (GPA) range between 68 and 92 out of 100. The ages of a total of 20 parents range between 38 and 55. Two of the parents are fathers, while 18 are mothers. 14 of the mothers are housewives. Parents' education levels vary between primary school and university.

\section{Data Collection}

Since the interviewing is recommended as the main data collection tool (Büyüköztürk et al., 2018) within the scope of phenomenological model, a semistructured interview form, including five open-ended questions, was used in this study to identify the views of the students and parents directly in a detailed manner. These questions are related to the evaluations by the students and parents about the impacts of COVID-19 pandemic on the preparation period for HEIE, to whether their concerns have changed in time with the pandemic and to their evaluations about the advantages and disadvantages of preparing for the exam in this period. Upon the creation of the draft form, two experts, who completed their Ph.D. in the fields of education programs and training as well as guidance and psychological counseling, were told the purpose of this research and their opinions were received in relation to the interview form. The experts recommended that the questions including "a reason why" be structured as open-ended questions, which would enable students to answer the questions by having more in-depth considerations on the situations they would be in and that two of the questions be removed from the form as they would not serve the purposes of the 
research. In line with these opinions of the experts, necessary revisions were made and the forms were finalized for implementation. The pilot implementation was carried out with the participation of three students and three parents, bearing similar characteristics to those in the study group, at the end of which interview forms were finalized.

The interviews were conducted via teleconference due to COVID-19 pandemic. To ensure the anonymity of the participants, each participant was connected to the teleconference programs, the interviews were recorded only as audio, and video recording was not available. In order to prevent students from feeling as if they had to agree with their parents and to ensure that they could express themselves well in the interviews where parents and students were together, individual interviews were held online with them in a way to ensure that first students then their parents would be separately interviewed. Interviews took place at different times in accordance with the convenience of the students and their parents. A total of forty different sessions were held, once for each student and parent. At the beginning of the interview, participants were explained the purpose of the research as well as being provided with such information and assurance as the fact that the participation was voluntary, that their rights to withdraw from the research at any stage resided, that privacy of the identity information and anonymity would be protected and that the information provided would only be used within the scope of a scientific research study. After such information, the consent of the participants was obtained, and interviews of approximately 25-30 minutes were conducted. After completing all the interviews, the records were transcribed in writing and shared with the participants for confirmation.

\section{Data Analysis}

For the analysis of the data obtained from the study, the content analysis technique was employed to make replicable and valid inferences from texts and similar important materials (Krippendorff, 2004). A categorical system reflecting basic elements in the relevant text through content analysis is created by deduction (theoretically produced based on the literature) or induction (produced based on the data set). If the purpose of a study is revealing findings, the use of induction method is recommended. Within this context, the data were analyzed with an inductive iterative process in this study, as suggested by Braun and Clarke (2006). As suggested by Patton (1999), the expertise of a different expert working in the field of qualitative data analysis than the researchers was benefitted from. The academician in question completed his Ph.D. in the field of Education Programmes and Training. With the analysts whose expertise was used during the data analysis process, authors who completed their Ph.D. in the field of Assessment and Evaluation in Education and who was continuing their Ph.D in the field of Educational Psychology coded the transcripts individually at first, then worked together to refine the preliminary themes and create the main themes. Analysis process was carried out with cyclical and continuous comparisons (Glaser \& Strauss, 1967) made in the form of code development/refinement and theme development/refinement. In the end, final themes were introduced as an output of discussions on analysts' comments (Richards \& Morse, 2013). As suggested by Bree and Gallagher (2016) and Meyer and Avery (2009), MS Microsoft Excel program was used for the data analysis. Popular software such as NVivo, MAXqda, ATLAS.ti, CAQDAS, which are used in data management and were designed to 
organise unstructured qualitative data (Zamawe, 2015), are tools having a supporting nature only. In addition, as Faherty (2010) stated, only the researcher can analyze qualitative data. Although each software has different pros and cons in terms of data management, MS Word tables and MS Excel macros are also preferred in qualitative data analysis (Bree \& Gallagher, 2016; La Pelle, 2004; Meyer \& Avery, 2009). Since coding is a critical step in analyzing qualitative data (Ose, 2016), qualitative data analysis was carried out using MS Excel in this study because it allows systematic coding in a simple and user-friendly manner.

\section{Trustworthiness}

As the qualitative research studies are not based on statistical calculations due to their nature (Brink, 1991), they are often criticized for being subjective, lacking a systematic structure, and deficient reporting. In this regard, the criteria to increase the quality of the data in the qualitative research are discussed in the literature (Guba, 1981; Lincoln \& Guba, 1986; Maxwell, 1992). Examining these discussions, it is seen that such concepts as credibility and transferability replace the concepts of validity and reliability in qualitative research studies (Corbin \& Strauss, 2007; Eisner, 1991, as cited in Creswell, 2013, p. 246). To increase the conclusiveness (internal validity) of the data in this research, necessary sampling scale for phenomenological model was achieved (Charmaz, 2011; Creswell, 2013; Merriam \& Tisdell, 2016). Data collection tool, data collection and analysis were reported in detail, by which transferability (external validity) of the research was tried to be ensured (Yıldırım \& Şimşek, 2011). Data analysis was conducted independently with an expert on qualitative data analysis other than researchers (Patton, 1999). After finalizing the themes and codes, the percentage of agreement was calculated as suggested by Miles and Huberman (1994), and the resulting percentage (92\%) was found to be sufficient for coding reliability (Miles \& Huberman, 1994).

\section{Findings}

The research findings have been presented under five categories in parallel with the sub-objectives of the research. In the descriptions of categories, themes, sub-themes, codes, and frequencies of these codes have been given successively for students and parents. In terms of the clarity and simplicity of the findings obtained from the research, the most striking views related to the codes in each category are presented directly with quotes.

\section{Findings of the Impact of COVID-19 Pandemic on the Preparation Period for the Exam}

The views of both students and parents collected in relation to the impacts of COVID-19 pandemic on the preparation period for the exam have been interpreted under two main themes, namely "Impacts" and "Coping Strategies".

\section{“Impacts” Theme}

Under "psyco-social" sub-theme within the scope of this theme, students mentioned their health concerns raising in line with the pandemic $(f=5)$, social isolation $(f=2)$ they have experienced as a result of health and safety policies, extreme stress $(f=2)$ as well as feeling of emptiness $(f=2)$. Under "Educational" sub-theme, students 
mentioned reduced motivation $(f=11)$, uneasiness caused by lack of doing different activities $(f=1)$, distractibility $(f=1)$, inefficacy of online education $(f=8)$, lack of a structured educational environment and support $(f=9)$ as negative impacts while they mentioned flexible time $(f=2)$ facilitated by the changing education paradigm as a positive impact of the pandemic.

"I felt empty. People are dying, everything has been shut down. How can we be expected to study efficiently..." (S13)

"We don't know what hit us, we can't go out to breathe or distract ourselves, we are with the same people caged within four walls. We can't be with the people we love, which affects us significantly." (S4)

"It ruined everything. Knowing that I have to study for the exam while there are already problems and distress caused by the pandemic decreases the determination to study even more. Hearing that something is happening to the people around causes an increased feeling of emptiness and hinders studying for a certain period." (S1)

"It affects me negatively as I can't get face-to-face education. The higher the fear of losing my relatives is, the lower my motivation gets." (S7)

"In fact, the pandemic gave extra time, but the distress and fear caused by it were quite enough. I lost my motivation to study because one of my family members went through a difficult time right before my eyes. The fear of infection has caused a lot of distress". (S11)

"Being at home most of the time gave me the opportunity to study harder, but also the school closures affected me badly. The pandemic lowered my motivation. There are people at home with chronic conditions. I couldn't get anywhere because I was afraid that if I got sick, I would infect them. Being at home all the time disrupted my psychology, I became depressed." (S12)

Under "Impacts" theme, the parents mentioned, similarly to the students, health concerns $(f=2)$ and stress $(f=2)$ as well as referring to psycho-social impacts, differently from the students, such as uncertainty $(f=1)$, difficulty in adapting to the process $(f=1)$, lack of activities $(f=1)$. Furthermore, parents pointed out, just like students did, to the inefficacy of online education $(f=3)$, low motivation $(f=8)$, problem of distraction $(f=2)$, by also referring additionally to "Educational" impacts such as deprivation of educational environment and support $(f=13)$, lack of discipline imposed by school $(f=1)$, opportunity to study harder $(f=1)$ and lack of studying /giving up studying $(f=1)$.

"It affected badly. The student got even more stressed. Being away from his/her teachers and friends, restrictions..." (P4)

"I am thinking about my child. I'm afraid s/he'll get sick, stressed out. The restrictions limited my child's life in many ways, which, in turn, stresses him/her out and overwhelms him/her..." (P11)

"Because s/he's always at home, s/he devotes more time to her/his lessons, but s/he's distracted and not very enthusiastic." (P16)

"I think the pandemic affected badly. We cannot fill the gap of face-to-face education no matter what we do. As their social lives have come to a halt, s/he forces her/himself to study continuously... S/he was not a child who liked staying at home, so her/his motivation decreased..." (P5)

"It affected badly. S/he experienced the problem of distraction. S/he doesn't sit at a desk, even if s/he does, s/he cannot study." (P10)

\section{“Coping Strategies” Theme}

The student and parents also mentioned "Coping strategies" related to the fight with the impacts apart from the impacts of COVID-19 pandemic on the preparation period for the exam. 
Under the "Strategies" sub-theme, it has been seen that students adopted such ways as dreaming about the university/profession they wanted $(f=1)$, self-motivating by thinking that their rivals were in the same situation as them $(f=1)$.

“...I try to study by thinking that as everybody has been going through the same psychological process, if I study harder, I can turn this situation into an advantage." (S4)

“...to increase my motivation, I think about my future profession, and dream about it, so I can study." (S9)

As for the parents, they stated, under "Strategies" sub-theme that they had limited means to support their children due to social isolation $(f=8)$, but they did all they could to provide moral support $(f=9)$, that they helped children in planning the process for their studies $(f=1)$.

"...I, most of the time, try to drive my child to picnic areas to improve his/her motivation. While s/he does test, I read a book." (P5)

"...I am trying to do what s/he likes for the sake of the family itself, as well." (P11)

“...we have explained him/her that s/he is not the only one being in this situation, which applies everybody preparing for the exam, and the pandemic should not affect him/her motivation. We have talked to him/her and helped in making his/her plans and programs. To restore his/her motivation to study, we have done intra-family activities, and by buying various gifts, course materials and tools, we have tried to help him/her restore his/her motivation." (P12)

\section{Findings Related to the Most Concerning Issues about the Exam}

While student views on the most concerning issues about the exam were collected under two main themes, namely "Educational" and "Psycho-social", it was identified that parents, additionally, expressed their views under "Health" theme.

\section{"Educational" Theme}

A significant part of the students expressed such fears, under "Examination system/period" sub-theme, as failure to complete the exam questions on time $(f=5)$, failure to understand subjects all by himself/herself during online education $(f=4)$, mind blanks $(f=2)$, being late for the exam $(f=1)$. Under "Educational outputs" sub-theme, students expressed their concerns about such potential consequences as obtaining low scores from the exam $(f=1)$, and failure to pass the exam $(f=10)$.

"The examination system, all by itself, is my reason for fear. I am afraid of being inadequate. (S6)

"I have started to worry about whether I can understand the subjects and learn them all in time." (S9)

"I think that online education is inefficient during the pandemic. I am worried because all these subjects will constitute the contents of the exam questions." (S16)

"I already think that I will fail to be placed in a university as a result of the exam, but still getting low scores worries me." (S1)

"I am afraid of forgetting what I know due to stress and failing to complete the exam questions on time." (S10)

"I am afraid of failure." (S11)

"I am afraid of forgetting everything because of stress and failing to complete exam questions on time." (S14)

A significant part of the parent concerns was related to "distance education" sub-theme. Within this context, the parents expressed their views about their doubts of the effectiveness of online education $(f=3)$, the length of the process $(f=1)$ and their 
children's deprivation of teacher support $(f=1)$. Under "Academic motivation" subtheme, parents pointed out to the lack of motivation experienced by their children $(f=1)$ and to the insufficient effort made by the children $(f=1)$, accordingly in terms of studying. Similar views of the parents to the students were categorised into "Educational outputs." In this regard, parents expressed their concerns about their children's failure $(f=10)$ by reasoning it with the worry that students might not learn all the subjects in time and complete the exam questions on time $(f=2)$.

"The course of the pandemic; if the virus continues to spread rapidly and the courses continue via distance education, what if my child receives an education of poor quality, lacks good education.” (P13).

"Pandemic affected children badly. There is a disconnection between children and school and classes, my child lost his/her enthusiasm because of the disinterested and unsupportive teachers. We are in contact with my child's teachers, and I think deep down that my child will not be able to succeed." (P9)

"I am concerned about what if s/he got stressed and could not answer the questions. If s/he experiences a mind blank and cannot complete the exam questions on time, both s/he and we will become sad.” (P15)

\section{"Psychosocial" Theme}

Students not only suffer from educational problems related to the exam but also have some concerns within the "Psycho-social" context. Some concerns, especially, fall into the scope of "Environmental" factors such as family pressure $(f=2)$ and of "Personal" factors such as failure to become financially independent $(f=1)$, efforts to go down the drain $(f=1)$, concern for future $(f=1)$, failure to achieve goals $(f=2)$ and failure to be placed in a university $(f=2)$.

"Increased family pressure due to concern for future worries me a lot. Concern for future, will I be able to be placed in a university, will I be able to find a job even if I get my degree, all of these are question marks in my mind." (S4).

“...I am afraid of my family's pressure and my efforts to go down the drain." (S7)

"I am concerned about failing to achieve my goals and be placed in a university." (S18)

"I have concerns such as looking to others and being dependent for my living." (S8)

As for the parent concerns within "Psycho-social" context, they include their children's getting excited and stressing out $(f=5)$ and "Personal" factors such as children's getting upset $(f=1)$. Additionally, parents were identified to have fears such as their children's being influenced by their friends under "Environmental" factors $(f=1)$ and concerns for future $(f=2)$ similar to the students.

"The most concerning issue about the exam is our child's stress condition. S/he feels too much under stress and we worry that s/he cannot take his/her stress under control during the exam." (P12)

“...I also worry about my child's being influenced negatively by his/her friends.” (P3)

"Concern for future and whether s/he ends up being unemployed or not worry us every single day." (P14)

\section{"Health" Theme}

Unlike students, parents have concerns about "Health" aspect of the examination. The views of the parents concerning about physiological and psychological impacts of the exam were evaluated under "Pandemic" sub-theme, and it 
was observed that they have health concerns and health problems $(f=1)$ related to COVID-19.

"... and the pandemic preoccupies me" (P1).

"What if something happens to wear my child out physiologically or psychologically." (P5)

"Because of the pandemic, I'm worried about virus infection in such a crowded examination environment." (P11)

Findings on Changes in Exam-Related Concerns during COVID-19

\section{Pandemic}

Student and parent views on the changes in their concerns emerging during COVID-19 pandemic were grouped under two main themes, namely "Stable" and "Changes".

\section{"Stable" Theme}

Student views under "Stable" theme have showed that students had the same concerns in relation to the exam before the pandemic $(f=17)$, which did "not change at all". On the other hand, it has been observed that some students expressed that their already existing concerns became more overwhelming and greater, that is, "Increased" in line with the pandemic $(f=3)$.

"My concerns did not change." (S13).

"I had the same concerns before the pandemic because changing examination system is the biggest factor bothering me." (S17).

"Even before the pandemic, I had the same concerns, but they were only a few because my motivation was higher then." (S1)

"Even before the pandemic, I had the same concerns, but they were not so overwhelming. I used to think that I could catch up and prepare by receiving support. However, I don't feel so, now." (S18)

A similar situation has also been observed in the case of parent views. The findings have revealed that most parents had the same concerns $(f=14)$; thus, their concerns did "not change at all" and others expressed that the same concerns became more overwhelming and greater, that is, "Increased" $(f=1)$.

"Even before the pandemic, we had these concerns (referring to the stressful temperament of his/her child). We have the same concerns, now, as well. I can say that we are even more concerned." (P12)

"I had the same concerns about the exam before the pandemic." (P15).

\section{"Changes" Theme}

Under "Changes" theme, student views expressing that they did not have the concerns before the pandemic they currently have were included. Within this context, it was that some of the student concerns are related to "Educational" factors and that students pointed out to lack of educational support $(f=4)$, motivational problems $(f=1)$ and the examination system itself $(f=1)$ as the problem. Moreover, some students expressed their concerns in relation to "Educational outputs" such as failure to achieve goals $(f=1)$.

"Before the pandemic, I didn't have any fear of catching up with exam subjects or my capability to succeed because there were people that could be of help, I could ask my questions to both my friends and teachers, but now, I am all alone.” (S9) 
"Even before the pandemic, I had the same concerns, but they were not so overwhelming. I used to think that I could catch up and prepare by receiving support. However, I don't feel so, now." (S18)

"No, I did not have the same concerns. Before the pandemic, I was worried if I can't go to the university that I aimed for; however, I am almost certain about it because I can't do this without support, I can't catch up." (S20)

It has been established that parent concerns differed within "Educational" and "Psycho-social" contexts in line with the pandemic. In this regard, parents stated that they had fears related to efficacy of distance education $(f=2)$, lack of sufficient educational support $(f=1)$, and their children's failure $(f=4)$ within the scope of their "Educational" concerns, whereas, differently from the students, they expressed concerns within "Psycho-social" context by referring to their children's being influenced by their friends $(f=1)$, health concerns $(f=3)$, getting stressed $(f=2)$ and becoming unhappy $(f=1)$.

"I am afraid s/he won't get in a university and will become unhappy because he can't study at home as efficiently as the period before the pandemic." (P6)

"My concerns were the same then, but when the education evolved to be distance education, I started to concern about my child's not getting as efficient education as before." (P2)

"Before the pandemic, only my child's own stress used to upset me, but now there is also the risk of this disease. (P11)

"Before the pandemic, I was worried that my child would not take the exam seriously. That he's completely disconnected from the process and depressed concerns me now." (P20)

"Before the pandemic, I used to worry mostly about the result that my child will get out of the exam, but now, his/her stressed condition at home worries me even more." (P13)

\section{Advantages of Preparing for the Exam during COVID-19 Pandemic}

Students and parents addressed the "Educational" and "Psycho-social" advantages of preparing for the exam during the pandemic.

\section{"Educational" Theme}

Students expressed, under "Autonomy" sub-theme, that exiting a system structured against their will with COVID-19, provided them with more time $(f=2)$ and freedom $(f=5)$. They expressed, under "Physical factors", that they happened to have a more comfortable studying environment $(f=4)$, that there were fewer distracting factors $(f=1)$, and that they got less tired $(f=4)$ than before.

"Staying home, studying more comfortably and freer." (S19)

"I had more time, which was an advantage for me." (S13).

"There are no distractions such as commutes, friends." (S1)

"The advantage is that as we are home, we are not tired from school or extracurricular courses, in turn, we can study at ease." (S18)

"It had only one advantage, yes. I don't get tired or lose time because of commuting between school and private tuition courses..." (S20)

It has been observed that most of the parents interpreted children's having a better opportunity to study $(f=4)$ as the only educational advantage and their related views were analyzed under "Time" sub-theme.

"S/he has more time for her/his own. S/he has a space for an efficient studying activity, we do our best to make him more comfortable at home." (P6)

"S/he doesn't lose time while commuting between home and tuition." (P9) 
"I think s/he has more time to study, to devote to her-/himself and his/her lessons." (P12)

\section{"Psychosocial" Theme}

Students pointed out to "Environmental" factors such as reduced motivation of their rivals $(f=3)$ and "Personal" factors such as having time for family $(f=1)$ as the psychological advantages of preparing for the exam during the pandemic.

“... it allows me more time to spend with my family." (S7)

"Most people gave up and if I don't give up, I can do very well." (S2)

"While everybody cares about the virus, if I care only about the exam, I can get ahead." (S3)

"Everybody will be affected by this situation, and lose their motivation, and if I can try to keep myself out of it, I can turn this pandemic into an advantage." (S4)

The advantages parents expressed within "Psycho-social" context were related to their control and supervision of their children. In other words, parents expressed that with the decrease in free time spent outside $(f=8)$, they found the opportunity to follow and supervise their children more easily $(f=4)$, which represents an important advantage within the scope of "Behavioural control"; and that with the increased time spent at home, peer influence got reduced $(f=1)$, which represents an important advantage under "Psychological control".

"S/he is not influenced by his/her friends." (P3).

"It's a good thing s/he's under my supervision." (P7)

"We are able to plan and supervise his/her studying at home better." (P10)

"It's easier for me to follow him/her because s/he's always in my sight at home." (P13)

“...As s/he cannot go out much, I can check whether s/he is studying or not." (P15)

"S/he has more free time at home. S/he can devote time to studying." (P20)

\section{Disadvantages of Preparing for the Exam during COVID-19 Pandemic}

Student and parent views on the disadvantages of preparing for the exam during pandemic were analyzed under three main themes, namely "Physical", "Psychological" and "Educational".

\section{"Physical" Theme}

Under "Physical" theme, students pointed out to insufficient activities $(f=2)$, risk of getting down with the virus $(f=1)$, obligation to stay home all the time $(f=3)$ as the disadvantages in relation to "Health".

“...Staying home demoralizes me.” (S3).

"After all, health is more important than anything, losing it affects our entire lives." (S11)

"Being under constant stress." (S12)

It has been observed that parents, similarly to the students, expressed their "health" concerns. Apart from their health concerns related to COVID-19 ( $f=1)$, it has been seen that parents also worry about, differently from the students, the fact that preparation period itself for the exam has negative impacts on health $(f=9)$.

"As s/he needs to go to private courses, we are afraid of virus infection." (P16)

"His/her health was adversely affected in every sense." (P6)

"My child is badly affected both emotionally and healthwise." (P10) 


\section{"Psychological" Theme}

"Psycho-social" disadvantages were addressed within the scope of the views expressed under "Psychological" theme, under which students mentioned longing for the past time, where this virus did not exist $(f=1)$, getting stressed $(f=2)$ and limited social circle $(f=1)$.

"Longing, friends' circle, lack of activity..." (S7)

"I am bored of lack of any activity." (S8)

Parents, similarly to the students, discussed "Psychosocial" disadvantages and pointed out to students' deprivation of social interaction $(f=2)$ and feeling depressed and difficulty $(f=6)$; however, differently from the students, they also mentioned that children experienced difficulty in adapting to the process $(f=1)$ and that this process caused uncertainty $(f=3)$.

"It has multiplied the stress of my already stressed child. As I worry about anything negative that may happen to him/her, I think it is a disadvantage." (P12)

“As we don't know the course of the situation, adaptation period to pandemic took long, which led my child to miss classes and, in turn, lack of knowledge about subjects. (P9)

"S/he became mentally depressed and ended up to fail in focusing attention, being home all the time." (P15)

\section{“Educational” Theme}

As "Educational" disadvantages, most of the students pointed out "Distance education" and the problems encountered due to its very nature. Lack of face-to-face education $(f=4)$, failure to understand the subjects by studying all by oneself $(f=2)$, inefficacy of online education $(f=4)$, lack of sufficient educational support $(f=9)$ was expressed as the disadvantages of this period. Additionally, differently from parents, students mentioned disadvantages related to "Academic motivation" such as decreased studying rates $(f=2)$, lack of motivation $(f=2)$, rivals' studying harder $(f=2)$.

“...I can't have immediate answers to my questions, and studying in the same environment with my sibling is challenging" (S7).

"As I have hard time in understanding the subjects taught on distance education, I lose more time." (S9)

"It is disadvantageous because I think receiving face-to-face education is more effective in terms of learning and understanding" (S19)

"Being caged within four walls demotivates me." (S1)

"Everyone has a lot of free time, and for me, it becomes a disadvantage if everyone focuses more on the lessons." (S4)

As for the parents, they discussed, similarly to the students, the problems encountered due to the nature of distance education under "Educational" disadvantages. Within this context, parents stated, under "Distance education" subtheme, that students lost motivation $(f=1)$ and suffered from the lack of educational support $(f=2)$ as well as discussing their doubts about the efficacy of distance education $(f=2)$ and students' deprivation of the opportunities yielded by face-to-face education $(f=3)$.

"In terms of low motivation, this period is far more disadvantageous." (P13)

"Due to the restrictions, I can't do my best for my child, nor can I provide necessary support." (P1) 
"I cannot provide the opportunity for tuition or other courses than school to support my child's education." (P3)

“...s/he cannot learn efficiently from distance education." (P19).

"S/he cannot put the education received in full practice." (P20).

\section{Discussion}

It has been challenging for both educators and students to meet the usual standards of Higher Education Institutions Examination (HEIE), which is an exam concerning millions of students in Turkey and implement HEIE in accordance with the public health policies coming up with COVID-19 pandemic. As noted in UNESCO's report (2020), countries have adopted various strategies for high-stakes exams like HEIE during COVID-19 pandemic, such as canceling, postponing, rescheduling, and organizing the exams on an online platform. At first, Turkey postponed HEIE and decided that HEIE would be held when contained social life would be in effect (UNESCO, 2020). Although it was a challenging task, it can be stated that HEIE implemented in 2020 by the traditional paper and pencil method was carried out successfully with all personal protection measures and security put in place. However, the findings obtained from this study show that this is a difficult situation to adapt to for students to enter HEIE in 2021 and for their parents. Within this context, the findings of this study are discussed below under four main headings in the light of literature.

\section{Impact of COVID-19 Pandemic on the Preparation Period for the Exam}

Evaluating the findings of this study about the impact of COVID-19 pandemic on the exam preparation process, it is seen that both students and parents discussed psychological and educational impacts. In this context, it has been determined that students and parents similarly expressed health concerns, problems caused by low motivation, extreme stress and distraction problems. Uncertainty about the restoration of normal life increased stress and anxiety in both parents and students (Daniel, 2020). Evaluating the findings in terms of differences between the student and parental perspectives, it has been seen that the students expressed that they found it pointless to study for the exam during such a difficult time and that they felt emptiness while parents expressed the lack of discipline imposed by school. When an individual's world turns upside down due to something as chaotic as COVID-19, it can result in the individual thinking that their work is petty or even completely pointless (Martela \& Kent, 2020). In this context, it is quite an ordinary reaction for students to question the meaning of them studying through these difficult and unusual times. However, finding a purpose in such situations makes it bearable for the individual (Martela \& Kent, 2020). As a matter of fact, the findings have also shown that students strive to be motivated by thinking about their desired profession or their rivals in order to fight against negative impacts of COVID-19 pandemic on the preparation period for the exam. In a sense, this can be interpreted as students trying to reduce the negativity caused by the period by reminding themselves of their goals. Findings have revealed that parents' coping strategies were quite different from those of students. It has been determined that parents expressed that they helped their children make studying plans and provided moral support within restrictions due to public health policies and limited social opportunities. According to a study on high-stake exams conducted by Barksdale-Ladd and Thomas (2000), it was seen that while some parents expressed that they helped their 
children by using methods such as preparing them a rich breakfast during their preparation period for the exam, others expressed that they supported their children by pressuring them to complete their study or providing additional educational materials.

\section{The Most Concerning Issues about the Exam}

Due to the lack of a structured school/educational environment, the lack of opportunities offered in traditional formal education, infrastructural incapacity and the lack of strategies and materials used in education, students and parents are skeptical of the efficacy of distance education (Başaran et al., 2020). Indeed, the most concerning issues regarding the exam for the students and parents were the efficacy of distance education and the problems caused by the very nature of distance education. In addition, the students also expressed their concerns on the constant changes made to the examination system as well as the process and the consequences of the exam while the parents were concerned about their children's academic motivations in addition to the examination system. The findings obtained from this study show similarity to the findings in the studies conducted before COVID-19 pandemic, in which the constant changes made to Turkish education system were considered a major problem (TemliDurmuş \& Kasa, 2015). For example, in a study conducted by Karataş (2020), students stated that the changes made to the date of the central placement exam during COVID19 pandemic negatively affected their motivation and psychology.

The findings have shown that the most concerning issues about the exam were not only associated with educational problems and their potential consequences. Both the students and their parents were concerned about some psycho-social factors that were personal and environmental. Because of the infection risk of COVID-19, parents, unlike students, expressed health concerns specific to current time period. It was observed in a study conducted by Yörüsün (2020) that just as there were students concerned about getting infected before the exam, there were also students concerned about getting infected during the exam and then infecting their families; however, there have been no findings in the literature about the views of the parents concerning this issue. It is also known through literature that students experience physical and psychological problems (Abrams et al., 2003) such as anxiety, stress and fatigue due to reduced physical and social activities such as hobbies and art etc. (Lewis, 2003; Thomas, 2005) during the preparation period for high-stake exams. Indeed, it can be seen in this study that some parents' health concerns were not only limited to COVID19 but also related to these physical and psychological effects, which are in the very nature of the preparation period of the exam.

The findings of this study have shown that the most concerning issues about the exam included failure to be financially independent, efforts to go down the drain and the results of the exam according to the students while the parents were the most concerned about their children' experiencing more anxiety and stress, becoming unhappy and too susceptible to peer influence. Both students and parents expressed their concerns about the future. It is known that being part of an exam-oriented education system brings unhappiness (Altan, 2017) and that having constant test anxiety has negative physical and psychological effects on students (Dönmez, 2017). In this regard, it can be stated that COVID-19 pandemic makes the negative effects of an exam-oriented education system even more pronounced. Assessing how to recalibrate well-established curricula 
and evaluation traditions upon the pandemic makes it necessary to discuss the advantages and disadvantages of insisting on traditional assessment and evaluation practices. Even though exams constitute an important part of education, their clear association with the curriculum, far less effectiveness compared to global education systems and failure to meet the requirements of the time have made their presence questionable in the rapidly changing educational paradigm with COVID-19 pandemic. Considering that COVID-19 pandemic has made unequal opportunities even more pronounced (Saltürk \& Güngör, 2020) for students preparing for HEIE, it seems understandable that students preparing for the exam with limited opportunities and their parents have concerns for the future. It can be considered that concern for the future is also associated with the sociodemographic possibilities of students. This situation can be described as follows: "Just as families from middle-upper social classes pass on their economic and cultural savings to their children, families from lower social classes pass on their "concerns for the future" and "lack of self-confidence" to theirs." (Buyruk, 2008, p. 83)

\section{Changes in Exam-Related Concerns during COVID-19 Pandemic}

Examining the changes caused by COVID-19 pandemic on concerns about the exam, it has been found out that a great number of the students and parents stated that the concerns they expressed on the previous question did not change at all and others stated that while their concerns did not change, they became more visible and overwhelming. On the other hand, some students and parents expressed changes in the content of their concerns with the pandemic. The hyper-arousal caused by COVID-19 pandemic may have led to an increase in both general and specific concerns about the exam (Karataş, 2020). As a matter of fact, it is observed in the literature that during COVID-19 pandemic, majority of students showed signs of anxiety (Cao et al., 2020).

The findings obtained from this study have revealed that the concerns of students expressing changes in their concerns about the exam with the pandemic were related mainly to academic motivation, lack of necessary educational support and to the context of changing educational paradigms, while some students were concerned about failing to achieve their goals because of these problems. In central placement exams, students adopt a mindset more concerned about test results rather than the quality of education (FairTest, 2007; Schrag, 2000) and receive additional lectures outside school (Saito, 2006; Ural \& Erktin, 2002). It can be stated that as they cannot carry out such activities due to the pandemic, students' anxiety increases. Similarly to the students, parents expressed concerns about the outcomes of the changing educational paradigm and, differently from the students, the health of their children.

\section{Advantages and Disadvantages of Preparing for the Exam during COVID- 19 Pandemic}

In this study, both the students and parents emphasized having more time to study as an advantage of preparing for the exam during COVID-19 pandemic. In this regard, unlike their parents, students pointed out, apart from the extra time, to the autonomy of existing a structured system and to the advantage of having fewer distracting factors (friends, noise, time lost on the way to school etc.). As a matter of fact, conducted studies show that despite the skeptical positions regarding the efficacy 
of distance education (Başaran et al., 2020), it also has some attractive aspects such as autonomy and flexibility provided to the students about the time and place to study (Kurnaz \& Serçemeli, 2020; Saltürk \& Güngör, 2020). Similarly, in this study, most of the students and parents expressed that lack of sufficient educational support was the leading factor they were concerned about and the main disadvantage in relation to preparing for HEIE during the pandemic; however, they also expressed that because of the autonomy and extra time it provided to the students, this process could be turned into an advantage.

In regard to the advantages of preparing for the exam during the pandemic, students and parents stated their views not only on psychological but also on educational advantages. It has been identified within this context that the views of the students and parents are quite different from each other. While students stated that their rivals' getting demotivated and their extra time to spend more with their families constituted the advantages, parents saw increased control and supervision over their children as an advantage. Time spent at home increased due to the public health policies, which increased the psychological and behavioral control parents had over their children. Accordingly, the parents interpreted this extraordinary period as an advantage in terms of preparation period for the exam. The parents stated that in this way, they could more easily control if their children were studying or not, plan their studies and check peer influence. Saito (2006) also found in his study concerning highstakes exams in Japan, which has a collectivist structure that parents practice strict control in relation to high-stake exams. In cultures where access to qualified education is limited (e.g., Asian cultures), the importance given to academic achievement is very high. Thus, academic achievement-oriented control practices do not negatively affect young people in Asian cultures (Chao, 2001). When the determining role of parents in students' academic achievement is evaluated (Jeynes, 2012), it can be assumed that such control-oriented practices may have become more functional during COVID-19 pandemic since students have had to fight against uncertainty.

As part of public health policies in Turkey, curfew restriction was imposed for individuals under the age of 20 as of April 4, 2020. Afterward, in line with the course of the pandemic, they were allowed to go out at specific times on certain days on the condition that they respected the rules of social distancing and using masks (Ministry of Interior General Directorate of Provincial Administration, 2020). The findings of this study have shown that both students and parents treat problems caused by lack of activity as disadvantages of preparing for the exam during COVID-19 pandemic. Lockdown and staying in the same environment at home all the time negatively affect the physical and mental health of students. Students, in this regard, expressed that they were longing for the past while parents emphasized the difficulties their children faced in adapting to this period. Similarly, it was found out in a research conducted by Yörüsün (2020) that social isolation policy implemented as a result of COVID-19 caused students to feel like they had to study constantly and to stress out due to always staying at the same environment, and in a study conducted by Karataş (2020) that students were longing for their schools.

Another issue both students and parents discussed as the disadvantage of preparing for the exam during the COVID-19 pandemic is related to educational factors. The findings of this study have shown that there were difficulties in adapting to 
online/distance education, that reservations about adopting changing educational paradigms and deprivation of social and academic support on educational terms were interpreted as disadvantages by both the students and parents, and that students' motivation was reduced. It was seen in another study that students and parents had doubts about the efficacy of online/distance education launched because of the pandemic (Başaran et al., 2020).

\section{Conclusion}

As can be understood based on the findings obtained from this study, distance and online education, which a vast majority of student population has had to switch to with COVID-19 pandemic, is not only a problem solely limited to the access to technology, but it also reflects basic faults and development inequalities. However, students fight against the increased stress stemming from the transition to distance education and against a limited student life experience. All students - especially those preparing for the exam, which stands as a cornerstone in their lives- would like to feel valued and supported socially and academically in their learning. Developing strong bonds with peers and teachers creates positive relationships that motivate students to do their best. Nonetheless, the safety policies implemented for public health have led to the weakening of such support systems. At this point, it is certain that approaches towards educational technologies with suspicion will not help. However, the way the technology is integrated into the assessment and evaluation processes is a pedagogical issue that can create unexpected problems if it is prescribed only by education bureaucrats.

In conclusion, this study is an early overview of the views of the high school students and their parents about preparing for HEIE during COVID-19 pandemic. Although stress is a natural part of the preparation period for the exam for many students, new stress sources have come into the picture with the pandemic. The anxiety experienced by the students and parents during their efforts to prepare for the exam has become overwhelming. In this regard, it is believed that this study, which addresses student and parent views on preparing for the university admission exam, deeply affecting the lives of millions of students during COVID-19 pandemic, may serve as a source for other studies to discuss a similar subject.

\section{Limitations and Suggestions}

The most important constraints of this study are as follows: The data were (i) collected only from the fourth-year students of an Anatolian high school (ii) in relatively early stages of the preparation period for the exam and (iii) the sample examined was small-scaled. In further studies, the data can be collected at different periods of time according to the course of the pandemic and the date of the exam. A larger-scaled sample can be included in the study (e.g., both parents can be participants). A comparative analysis can be carried out between the views of the students who graduated from high school but preparing for the exam once again and the views of the students continuing their high school education. The metaphors students produce about the impacts of the pandemic can be analyzed to examine their experiences further. A study conducted in the United States shows that students who have just started higher education have put their enrollment on hold until they return to face-to-face education to avoid missing student life experiences (Johnson, 2020). 
Similarly, as per the data of Student Selection and Placement Centre (ÖSYM, 2020b), there were 594,010 students having earned the right to make preferences among universities but did not according to the results of HEIE 2020. Considering this fact, a longitudinal study can be further conducted, and a post-exam review can be carried out on the educational process of the students in accordance with the course of the pandemic and students' rates of registration in the programs can be comparatively analyzed.

\section{Statement of Responsibility}

Aylin Saltürk and Ömay Çokluk-Bökeoğlu contributed equally to the design and implementation of the research, to the analysis of the results and to the writing of the manuscript.

\section{Conflicts of Interest}

The authors declare no conflict of interest. 


\section{References}

Abrams, L. M., Pedulla, J. J., \& Madaus, G. F. (2003). Views from the classroom: teachers' opinions of statewide testing programs. Theory into Practice, 42, 18-29. https://doi.org/10.1207/s15430421tip4201_4

Altan, M. Z. (2017). Standartlaştıran, tek tipleştiren, zarar veren ve mutsuzluğa açılan kapı: TEOG. Eğitime Bakış: Ĕ̆itim-Öğretim ve Bilim Araştırma Dergisi, 13(40), 4-14.

Arslan, M. (2004). Eğitim sistemimizin kapanmayan yarası: Yükseköğretime geçiş. Erciyes Üniversitesi Sosyal Bilimler Enstitüsü Dergisi, 1(16), 37-51.

Ayvacı, H. Ş., Bakırcı, H., \& Başak, M. H. (2014). Fatih projesinin uygulama sürecinde ortaya çıkan sorunların idareciler, öğretmenler ve öğrenciler tarafından değerlendirilmesi. Yüzüncü Yıl Üniversitesi Eğitim Fakültesi Dergisi, 11(1), 20-46.

Barksdale-Ladd, M. A., \& Thomas, K. F. (2000). What's at stake in high-stakes testing: teachers and parents speak out. Journal of Teacher Education, 51(5), 384-397. https://doi.org/10.1177/0022487100051005006

Baş, G., \& Kıvılcım, Z. S. (2019). Türkiye'de öğrencilerin merkezi sistem sınavları ile ilgili algıları: bir metafor analizi çalışması. Eğitimde Nitel Araştırmalar Dergisi, 7(2), 639-667. https://doi.org/10.14689/issn.2148-2624.1.7c.2s.8m

Başaran, M., Doğan, E., Karaoğlu, E., \& Şahin, E. (2020). Koronavirüs (Covid19) pandemi sürecinin getirisi olan uzaktan eğitimin etkililiği üzerine bir çalışma. AJER-Academia Ĕ̈itim Araştırmaları Dergisi, 5(2), 368-397.

Basic Law of National Education (1973, June 14). Turkey - Legal Gazette, (Nu.14574). https://www.mevzuat.gov.tr/MevzuatMetin/1.5.1739.pdf

Baştürk, S. (2011). Üniversiteye giriş sınavına hazırlanma sürecinin öğrencilerin matematik öğrenmeleri üzerine olumsuz yansımaları. Hacettepe Üniversitesi Ĕgitim Fakültesi Dergisi, 40(40), 69-79.

Braun, V., \& Clarke, V. (2006). Using thematic analysis in psychology. Qualitative Research in Psychology, 3(2), 77-101. https://doi.org/10.1191/1478088706qp063oa

Bree, R. T., \& Gallagher, G. (2016). Using Microsoft Excel to code and thematically analyze qualitative data: A simple, cost-effective approach. All Ireland Journal of Higher Education, 8(2), 2811-2824.

Brink, P. J. (1991). Issues of reliability and validity. In J. M. Morse (Ed.), Qualitative nursing research: A contemporary dialogue (pp. 164-186). Newbury Park, CA: Sage.

Buyruk, H. (2008). Eğitimde yaşanan toplumsal eşitsizliklere ilişkin biyografik bir araştırma [Yayımlanmamış yüksek lisans tezi]. Ankara Üniversitesi.

Büyüköztürk, Ş. (2016). Sinavlar üzerine düşünceler. Kalem Eğitim ve İnsan Bilimleri Dergisi, 6(2), 345-356.

Büyüköztürk, Ş., Çakmak, E., Akgün, Ö. E., Karadeniz, Ş., \& Demirel, F. (2018). Bilimsel araştırma yöntemleri. Ankara: Pegem.

Cao, W., Fang, Z., Hou, G., Han, M., Xu, X., Dong, J., \& Zheng, J. (2020). The psychological impact of the COVID-19 epidemic on college students in China. Psychiatry Research, 287. https://doi.org/10.1016/j.psychres.2020.112934 
Çelik, Z. (2015). Ortaöğretim ve yükseköğretime geçiş sınavlarının kıskacında ortaöğretim sistemi. Toplum Eğitim Politikalarl, 273-298.

Chao, R. (2001). Extending research on the consequences of parenting style for Chinese Americans and European Americans. Child Development, 72(6), 1832-1843.

Charmaz, K. (2011). Grounded theory methods in social justice research. In N. K. Denzin, \& Y. S Lincoln (Eds.), The SAGE handbook of qualitative research (pp. 359-380). Thousand Oaks, CA: SAGE.

Chirumamilla, A., Sindre, G., \& Nguyen-Duc, A. (2020). Cheating in e-exams and paper exams: the perceptions of engineering students and teachers in Norway, Assessment \& Evaluation in Higher Education, 45(7), 1-18. https://doi.org/10.1080/ 02602938.2020 .1719975

Çıngı, H., Kadılar, C., \& Koçberber, G. (2009). Türkiye'de ilköğretim ve ortaöğretim olanaklarının ilçe bazında incelenmesi. Hacettepe Üniversitesi Eğitim Fakültesi Dergisi, 36(36), 51-63.

Corbin, J., \& Strauss, A. (2007). Basics of qualitative research: Techniques and procedures for developing grounded theory (3rd ed). Thousand Oaks, CA: Sage.

Coşkun, C. (2019). Yeniden üretim sarmalında ĕgitimde firsat eşitsizliği: Malatya örneği [Doktora tezi]. İnönü Üniversitesi.

Creswell, J. W. (2013). Qualitative Inquiry \& research design: Choosing among five approaches (3rd edition). Thousand Oaks, CA: Sage.

Cüceloğlu, D. (2013). İnsan ve davranışı. İstanbul: Remzi Kitabevi.

Daniel, S. J. (2020). Education and the COVID-19 pandemic. Prospects, 49, 91-96. https://doi.org/10.1007/s11125-020-09464-3

Denzin, N. K., \& Lincoln, Y. S. (1998). Strategies of qualitative inquiry. Thousand Oaks, CA: 12 Sage.

Dermo, J. (2009). e-Assessment and the student learning experience: a survey of student perceptions of e-assessment, British Journal of Educational Technology, 40(2), 203-214. https://doi.org/10.1111/j.1467-8535.2008.00915.x

Dönmez, B. (2017). Türkiye'de temel eğitimden ortaöğretime geçiş sistemine ilişkin bir değerlendirme. Eğitime Bakış: Ĕ̆itim-Öğretim ve Bilim Araştırma Dergisi, 13(40), $26-31$.

Faherty, V. E. (2010). Wordcraft: Applied Qualitative Data Analysis (QDA): Tools for public and voluntary social services. Los Angeles, CA: Sage Publications

FairTest. (2007, December 17). The dangerous consequences of high stakes standardized testing. The National Center for Fair and Open Testing. http://fairtest.org/dangerous-consequences-highstakes-standardized-tes

Glaser, B. G., \& Strauss, A. L. (1967). The discovery of grounded theory: Strategies for qualitative research. Chicago, IL: Aldine Publishing Company.

Guba, E. (1981). ERIC/ECTJ Annual review paper: Criteria for assessing the trustworthiness of naturalistic inquiries. Educational Communication and Technology, 29(2), 75-91. 
Günbayı, İ., Yücedağ, F., \& Yücel, B. E. (2015). Fen lisesinde yaşanan sorunlara ilişkin öğretmen, öğrenci ve yönetici görüssleri: bir durum çalışması. Eğitim ve Eğitim Araştırmaları Dergisi, 4(2), 396-412.

Gür, B. S., \& Çelik, Z. (2009). Türkiye’de millî eğitim sistemi: Yapısal sorunlar ve öneriler. Ankara: SETA.

Gür, B. S., Çelik, Z., \& Coşkun, İ. (2013). Türkiye'de ortaöğretimin geleceği: Hiyerarşi mi eşitlik mi? Seta Analiz, 69, 1-26.

Hillier, M., Kumar, N., \& Wijenayake, N. (2020). e-Examinations: The impact of technology problems on student experience. In T. Brinda, D. Passey, \& T. Keane (Eds.), Empowering teaching for digital equity and agency (pp. 35-45). (IFIP Advances in Information and Communication Technology). Springer, Springer Nature. https://doi.org/10.1007/978-3-030-59847-1_4

Hodges, C., Stephanie, M., Lockee, B., Trust, T., \& Bond, A. (2020, March 27). The difference between emergency remote teaching and online learning, EDUCAUSE Review. https://er.educause.edu/articles/2020/3/the-difference-between-emergencyremote-teaching-and-online-learning

Jeynes, W. (2012). A meta-analysis of the efficacy of different types of parental involvement programs for urban students. Urban Education, 47(4), 706-742. https://doi.org/10.1177/0042085912445643

Johnson, R. (2020, April 20). Students stressed out due to coronavirus, new survey finds. Best College. https://www.bestcolleges.com/blog/coronavirus-survey/

Karataş, Z. (2020). Covid-19 pandemisi sürecinin LGS ve YKS sınavına hazırlık sürecinde olan çocuk ve ergenlerinin psikolojilerine yansımalarının incelenmesi. In Gençdoğan, B. (Ed). Pandemi döneminde çocuk ve ergen psikolojisi (ss. 54-74). Ankara: Türkiye Klinikleri.

Karsl1, M. D., \& Üstüner, I. Ş. (2001). Üniversiteye giriş sınav sistemindeki son değişikliğe ilişkin öğrenci algıları. Sakarya Üniversitesi Eğitim Fakültesi Dergisi, 2, 35-44.

Köse, M. R. (1999). Üniversiteye giriş ve liselerimiz. Hacettepe Üniversitesi Eğitim Fakültesi Dergisi, 15, 51-60.

Krippendorff, K. (2004). Content analysis: An introduction to its methodology (2nd ed.). Thousand Oaks, CA: Sage

Kumandaş, H., \& Kutlu, Ö. (2014). Yükseköğretime öğrenci seçmede ve yerleştirmede kullanılan sınavların oluşturduğu risk faktörlerinin okul başarısı üzerindeki etkileri. Türk Psikoloji Dergisi, 29(74), 15-31.

Kurnaz, E., \& Serçemeli, M. (2020). Covid-19 Pandemi döneminde akademisyenlerin uzaktan eğitim ve uzaktan muhasebe eğitimine yönelik bakiş açıları üzerine bir araştırma. Uluslararası Sosyal Bilimler Akademik Araştırmalar Dergisi, 4(1), 4053.

Kutsal, D., \& Bilge, F. (2012). Lise öğrencilerinin tükenmişlik ve sosyal destek düzeyleri. Ë̆itim ve Bilim, 37(164), 283-297.

La Pelle, N. (2004). Simplifying qualitative data analysis using general purpose software tools. Field Methods 16(1), 85-10. 
Lewis, A. C. (2003). Beyond testing. The Education Digest, 69, 70.

Lincoln, Y. S., \& Guba, E. G. (1986). But is it rigorous? Trustworthiness and authenticity in naturalistic evaluation. New Directions for Evaluation, 30, 73-84. https://doi.org/10.1002/ev.1427

Malee-Bassett, R., \& Arnhold, N. (2020, April 30). COVID-19's immense impact on equity in tertiary education. World Bank Blogs. https://blogs.worldbank.org/education/covid-19s-immense-impact-equity-tertiaryeducation

Martela, F., \& Kent, D. (2020, June 3). What to do when work feels meaningless. Harvard Business Review. https://hbr.org/2020/06/what-to-do-when-work-feelsmeaningless

Maxwell, J. (1992). Understanding and validity in qualitative research. Harvard Educational Review, 62(3), 279-301.

Merriam, S. B. (2009). Qualitative research: A guide to design and implementation. San Francisco, CA: Jossey-Bass.

Merriam, S. B., \& Tisdell, E. J. (2016). Qualitative research: A guide to design and implementation (4th ed.). San Francisco, CA: Jossey-Bass.

Meyer, D. Z., \& Avery, L. M. (2009). Excel as a qualitative data analysis tool. Field Methods, 21(1), 91-112. https://doi.org/10.1177/1525822x08323985

Miles, M. B., \& Huberman, A. M. (1994). Qualitative data analysis: An expanded Sourcebook (2nd ed). Thousand Oaks, CA: Sage.

Ministry of Interior General Directorate of Provincial Administration. (2020, December 01). Koronavirüs ile mücadele kapsamında - yeni kısıtlama ve tedbirler genelgeleri. https://www.icisleri.gov.tr/koronavirus-ile-mucadele-kapsaminda-sokaga-cikmakisitlamalari---yeni-kisitlama-ve-tedbirler-genelgeleri

Ministry of National Education [MoNE]. (2020a). Uzaktan eğitim sürecinin detayları. https://www.MoNe.gov.tr/uzaktan-egitim-surecinin-detaylari/haber/21990/tr

Ministry of National Education [MoNE]. (2020b). Millî eğitim istatistikleri örgün eğitim.

http://sgb.MoNe.gov.tr/MoNe_iys_dosyalar/2020_09/04144812_MoNe_istatistikler i_orgun_egitim_2019_2020.pdf

OECD. (2020). Remote online exams in higher education during the COVID-19 crisis, in OECD education policy perspectives, 6, OECD Publishing, Paris. https://doi.org/10.1787/5cc2d673-en

Ose, S. V. (2016). Using excel and word to structure qualitative data. Journal of Applied Social Science, 10(2), 147-162.

ÖSYM. (2017). ÖSYM Tarihsel Gelişme. https://www.osym.gov.tr/\%20TR,8789/hakkinda.html

ÖSYM. (2020a). $2020 \quad$ YKS Sinav Sonuçlarına Ilişkin Sayısal Bilgiler. https://www.osym.gov.tr/TR,19424/2020-yks-sinav-sonuclarina-iliskin-sayisalbilgiler.html

ÖSYM. (2020b). $2020 \quad$ YKS Yerleştirme Sonuçlarına İlişkin Sayısal Bilgiler. https://dokuman.osym.gov.tr/pdfdokuman/2020/YKS/sayisalbilgiler26082020.pdf 
Patton, M. Q. (1980). Qualitative evaluation methods. Thousand Oaks, CA: Sage.

Patton, M. Q. (1999). Enhancing the quality and credibility of qualitative analysis. HSR: Health Services Research, 34, 1189-1208.

Patton, M. Q. (2002). Qualitative research \& evaluation methods. Thousand Oaks, CA: Sage.

Richards, L., \& Morse, J. M. (2013). Read me first for a user's guide to qualitative methods (3rd ed.) Los Angeles, CA: Sage.

Rutz, H. J., \& Balkan, E. M. (2015). Sınıfın yeniden üretimi, eğitim, neoliberalizm ve Istanbul'da yeni orta sınıfin yükselişi. İstanbul: Ceylan Matbaası.

Saito, Y. (2006). Consequences of high stakes testing on the family and schools in Japan. KEDI Journal of Educational Policy, 3(1), 101-112.

Saltürk, A., \& Güngör, C. (2020). Üniversite öğrencilerinin gözünden covid-19 pandemisinde uzaktan eğitime geçiş deneyimi [Distance education in the Covid-19 pandemic from the perspective of university students]. Adiyaman Üniversitesi Sosyal Bilimler Enstitüsü Dergisi, 36, 137-174. https://doi.org/10.14520/adyusbd.788716

Schrag, P. (2000, August). High stakes are for tomatoes. The. Atlantic Monthly; 286 (2), 19-21. Retrieved from https://www.theatlantic.com/magazine/archive/2000/08/high-stakes-are-fortomatoes/378306/

Tabish, A. (2020). COVID-19 pandemic: emerging perspectives and future trends, $\begin{array}{llll}\text { Journal of public health research, 9(1), } 1786 . & .\end{array}$ https://doi.org/10.4081/jphr.2020.1786

Tansel, A., \& Bircan, F. (2005). Effect of private tutoring on university entrance examination performance in Turkey, IZA Discussion Paper No: 1609. Bonn, Germany: Institute for the Study of Labor (IZA). Retrieved from http://ftp.iza.org/dp1609.pdf

Temli-Durmuş, Y., \& Kasa, B. (2015). School principals and teachers' evaluations on the reasons decrease in University Entrance Exams. Journal of Educational Sciences Research, 5(1), 165-190.

Thomas, R. M. (2005). High-stakes testing: Coping with collateral damage. Lawrence Erlbaum Associates Publishers.

Turkish Statistical Institute [TurkStat]. (2019, May 15). İstatistiklerle gençlik. https://tuikweb.tuik.gov.tr/PreHaberBultenleri.do?id=33731

UNESCO. (2020). COVID-19 A glance of national coping strategies on high stakes examinations and assessments (Working Document). United Nations Educational, Scientific and Cultural Organization. https://en.unesco.org/sites/default/files/unesco_review_of_highstakes_exams_and_assessments_during_covid-19_en.pdf

Ural, O., \& Erktin, E. (2002). Merkezi seçme sınavı hazırlıklarında veli katkısı: Bir ölçek çalışması. Marmara Üniversitesi Atatürk Ĕ̈itim Fakültesi Eğitim Bilimleri Dergisi, 15, 183-192. 
Yıldırım, A., \& Şimşek, H. (2011). Sosyal bilimlerde nitel araştırma yöntemleri (8. Baskı). Ankara: Seçkin Publishing.

Yılmaz, K., \& Altınkurt, Y. (2011). Öğretmen adaylarının Türk eğitim sistemine ilişkin görüşleri. Uluslararası Insan Bilimleri Dergisi, 8(1), 943-973.

YÖK. (2020). COVID-19 bilgilendirme. Retrieved from https://covid19.yok.gov.tr/alinan-kararlar

Yörüsün, M. (2020). Koronavirüs pandemisinin yükseköğretim kurumları sınavına girecek öğrenciler üzerinde oluşturduğu etkiler. Kapadokya Eğitim Dergisi, 1, 7-11.

Zamawe, F. C. (2015). The implication of using nvivo software in qualitative data analysis: Evidence-based reflections. Malawi Medical Journal, 27(1), 13-15. 